\title{
HUBUNGAN ANTARA PENGETAHUAN TENTANG RESIKO TINGGI KEHAMILAN DENGAN SIKAP DALAM PEMERIKSAAN ANTENATAL CARE (ANC) DI PUSKESMAS SUNGAI RAYA DALAM TAHUN 2017
}

\section{Windiyati ${ }^{1}$, Denny Pebrianti ${ }^{2}$}

\author{
Akademi Kebidanan Panca Bhakti Pontianak
}

Email korespondensi: akbidpbpontianak@gmail.com

\begin{abstract}
Abstrak
Kehamilan beresiko tinggi merupakan kehamilan yang membahayakan, baik bagi sang ibu ataupun bagi janin yang dikandungnya. Sedangkan bahaya yang dapat timbul akibat ibu hamil dengan resiko tinggi yaitu, bayi lahir belum cukup bulan, bayi berat lahir rendah, persalinan tidak maju atau macet, perdarahan sebelum dan pasca persalinan, janin mati dalam kandungan, ibu hamil atau bersalin meninggal dunia, keracunan kehamilan atau kejang-kejang, dan keguguran. Penelitian ini bertujuan untuk mengetahui hubungan antara pengetahuan tentang resiko tinggi kehamilan dengan sikap dalam pemeriksaan antenatal care (ANC) di Puskesmas Sungai Raya Dalam tahun 2017. Desain menggunakan deskritif korelasi dengan cross sectional terhadap 34 responden yang memenuhi kriteria inklusi yang melakukan pemeriksaan kehamilan di Puskesmas Sungai Raya Dalam. Hasil penelitian sebagian besar dari responden 24 orang $(70 \%)$ berpengetahuan baik, sebagian besar dari responden 27 orang (79\%) memiliki sikap yang mendukung. Hasil perhitungan X2 hitung sebesar 8,27 sedangkan angka pada tabel chi square kuadrat tahap signifikasi 5\% = 2 adalah 5,991. Dengan demikian berarti 8,27 > 5,991 maka perhitungan Ho ditolak dan Ha diterima berarti ada hubungan antara pengetahuan tentang resiko tinggi kehamilan dengan sikap dalam pemerksaan antenatal care di puskesmas sungai raya dalam tahun 2017. Kesimpulan dari hasil penelitian ini adalah ada hubungan antara pengetahuan tentang resiko tinggi kehamilan dengan sikap dalam pemerksaan antenatal care di puskesmas sungai raya dalam tahun 2017. Oleh karena itu perlu adanya peningkatan pelayanan kesehatan terutama pemberian pendidikan kesehatan tentang resiko tinggi kehamilan melalui konseling dan penyuluhan kesehatan.
\end{abstract}

Kata Kunci: Pengetahuan, Sikap, Ibu Hamil, Antenatal Care

\section{Pendahuluan}

Menurut Mufdlilah (2009), antenatal care adalah suatu program yang terencana berupa observasi, edukasi dan penanganan medik pada ibu hamil, untuk memperoleh suatu proses kehamilan dan persalinan yang aman dan memuaskan. Menurut Lalage (2012), kehamilan beresiko tinggi merupakan kehamilan yang membahayakan, baik bagi sang ibu ataupun bagi janin yang dikandungnya.

Menurut Syaifuddin (2009), kondisi ibu hamil dengan resiko tinggi yaitu, ibu dengan tinggi badan kurang dari $145 \mathrm{~cm}$, bentuk panggul ibu yang tidak normal, badan ibu kurus dan pucat, umur ibu kurang dari 20 tahun atau lebih dari 35 tahun, jumlah anak lebih dari 4

\footnotetext{
${ }^{1}$ Dosen Akademi Kebidanan Panca Bhakti Pontianak

${ }^{2}$ Dosen Akademi Kebidanan Panca Bhakti Pontianak
}

orang, jarak kelahiran anak kurang dari 2 tahun, adanya kesulitan pada kehamilan atau persalinan yang lalu, sering terjadi keguguran sebelumnya, kepala pusing hebat, kaki bengkak, perdarahan pada waktu hamil dan batuk-batuk lama. Sedangkan bahaya yang dapat timbul akibat ibu hamil dengan resiko tinggi yaitu, bayi lahir belum cukup bulan, bayi berat lahir rendah, persalinan tidak maju atau macet, perdarahan sebelum dan pasca persalinan, janin mati dalam kandungan, ibu hamil atau bersalin meninggal dunia, keracunan kehamilan atau kejang-kejang, dan keguguran (Syaifudin, 2009). 
Menurut World Health Organization (WHO), setiap hari pada tahun 2015, sekitar 830 perempuan meninggal karena komplikasi kehamilan dan kelahiran anak. Penyebab utama kematian adalah perdarahan, hipertensi, infeksi, dan penyebab tidak langsung, sebagian besar karena interaksi antara kondisi medis yang sudah ada sebelumnya dan kehamilanya. Resiko seorang wanita di negara berkembang meninggal karena penyebab ibu terkait selama hidupnya adalah sekitar 33 kali lebih tinggi dibandingakn dengan wanita yang tinggal dinegara maju.

Lima penyebab kematian ibu terbesar yaitu perdarahan, hipertensi dalam kehamilan (HDK), infeksi, partus lama/macet, dan abortus. Kematian ibu di Indonesia masih didominasi oleh tiga penyebab utama kematian yaitu perdarahan, hipertensi dalam kehamilan (HDK), dan infeksi. Namun proporsinya telah berubah, dimana perdarahan dan infeksi cenderung mengalami penurunan sedangkan HDK proporsinya semakin meningkat (Profil Kesehatan Indonesia 2015).

Usia kematian terbesar pada ibu tahun 2015 yaitu pada usia 20-34 tahun sebanyak 4 orang sedangkan pada usia $\leq 20$ tahun sebanyak 1 orang. Kasus kematian ibu karena pre eklampsia (38\%), kasus infeksi (21\%), kelainan bawaan (17\%) dan lain-lain (24\%) (Profil Kesehatan Kota Pontianak, 2015).

Menurut Dinas Kubu Raya (2015), selama tahun 2015 ada 12 kasus kematian ibu yang ditemukan dan dilaporkan sebanyak 104,22 per seratus ribu kelahiran hidup, kasus itu berupa ibu hamil dengan hipertensi, perdarahan, gangguan sistem peredaran darah (jantung, stroke dll), gangguan metabolik berupa penyakit diabetes mellitus. Angka ini sama dengan kasus kematian di tahun 2014 yaitu sebanyak 12 kasus. Berdasarkan data diatas, kabupaten Kubu Raya tidak mencapai target MDG's 2015 yaitu 102 per 100.000 kelahiran hidup.

Pelayanan kesehatan ibu hamil yang diberikan harus memenuhi elemen pelayanan yaitu, penimbangan berat badan dan pengukuran tinggi badan, pengukuran tekanan darah, pengukuran lingkar lengan atas, pengukuran tinggi puncak rahim (fundus uteri), penentuan status imunisasi tetanus dan pemberian imunisasi tetanus toksoid sesuai status imunisasi, pemberian tablet tambah darah minimal 90 tablet selama kehamilan, penentuan presentasi janin dan denyut jantung janin (DJJ), pelaksanaan temu wicara (pemberian komunikasi interpersonal dan konseling, termasuk keluarga berencana), pelayanan tes laboratorium sederhana, minimal tes hemoglobin darah $(\mathrm{Hb})$,pemeriksaan protein urin dan pemeriksaan golongan darah (bila belum pernah dilakukan sebelumnya) dan tatalaksana kasus (Profil Kesehatan Indonesia 2015).

Sikap terhadap kesehatan adalah pendapat atau penilaian orang terhadap hal-hal yang berkaitan dengan pemeliharaan kesehatan. Sikap adalah juga respos tertutup seseorang terhadap stimulus atau objek tertentu, yang sudah melibatkan faktor pendapat dan emosi yang bersangkutan (senang-tidak senang, setuju- tidak setuju, baik- tidak baik, dan sebagainya). Dalam menentukan sikap yaitu, pengetahuan, pikiran, keyakinan, dan emosi 
memegang peranan penting (Syafrudin dan Yudhhia, 2009).

Pengetahuan tentang kesehatan adalah mencakup apa yang diketahui oleh seseorang terhadap cara- cara memelihara kesehatan. Pengetahuan atau kognitif merupakan dominan yang sangat penting dalam membentuk tindakan seseorang (overt behavior) (Notoatmodjo, 2010).

Menurut teori yang dikemukan oleh Lawrence and Green menyatakan bahwa seseorang tingkat pengetahuan yag tinggi akan lebih mudah dalam menyerap konsep-konsep kesehatan yang dipahami sehingga orang tersebut akan lebih memiki tingkat kesadaran untuk merubah perilakunya menjadi lebih baik dibandingkan yang mempunyai pengetahuan rendah, pengetahuan memiliki kaitan dengan sikap bahwa pengetahuan yang tinggi sikap untuk pemeriksaan antenatal care.

Berdasarkan hasil penelitian Sujati (2013), tentang “Gambaran pengetahuan ibu hamil tentang kehamilan resiko tinggi" diperoleh hampir setengahnya $(48,15 \%)$ sebanyak 13 responden berpengetahuan baik, hampir setengahnya $(29,63 \%)$ sebanyak 8 responden berpengetahuan kurang dan sebagian kecil $(22,22 \%)$ sebanyak 6 responden berpengetahuan cukup.

\section{Metode}

Penelitian ini menggunakan jenis penelitian deskriptif korelasional dengan pendekatan cross sectional. Penelitian dilaksanakan pada bulan Januari hingga Mei 2017 di Puskesmas Kampung Dalam. Populasi penelitian yaitu ibu sebanyak 363 orang. Peneliti menggunakan $10 \%$ dari jumlah populasi sebagai sampel sebanyak 34 orang. Pengumpulan data menggunakan kuesioner kemudian diolah dan dianalisis menggunakan analisis univariat serta analisis bivariat menggunakan uji chi square.

\section{Hasil dan Pembahasan}

Tabel 1. Karakteristik Responden

\begin{tabular}{lcc}
\hline \multicolumn{1}{c}{ Karakteristik } & $\mathrm{n}$ & $\%$ \\
\hline Pengetahuan & & \\
Baik & 24 & 70 \\
Cukup & 5 & 15 \\
Kurang & 5 & 15 \\
Sikap & & 21 \\
Tidak Mendukung & 7 & 79 \\
Memilih & 27 & \\
\hline
\end{tabular}

Berdasarkan tabel 1 Pengetahuan tentang resiko tinggi kehamilan dalam penelitian ini sebagian besar dari responden 24 orang (70\%) berpengetahuan baik, sangat sedikit dari responden berpengetahuan kurang 5 orang (15\%) dan Sangat sedikit dari responden berpengetahuan cukup 5 orang (15\%). Berdasarkan tabel 1 dari 34 responden sebagian besar dari responden 27 orang (79\%) memiliki sikap mendukung dalam pemeriksaan antenatal care. 
Tabel 2. Analisis Bivariat

\begin{tabular}{ccccccccc}
\hline & \multicolumn{9}{c}{ Tikap } & \multicolumn{2}{c}{ Total X Tabel } & \multirow{2}{*}{ X ${ }^{2}$ hitung } \\
\hline \multirow{2}{*}{ Variabel } & Mendukung & \multicolumn{2}{c}{ Memilih } & \multicolumn{2}{c}{ X } \\
& $\sum$ & $\%$ & $\sum$ & $\%$ & $\sum$ & $\%$ & & \\
\hline Baik & 22 & 81 & 2 & 29 & 24 & 70 & & \\
Pengetahuan Cukup & 3 & 11 & 2 & 29 & 5 & 15 & 5,991 & 8,27 \\
Kurang & 2 & 8 & 3 & 42 & 5 & 15 & & \\
\hline
\end{tabular}

Pengetahuan tentang resiko tinggi kehamilan dalam penelitian ini sangat sedikit dari responden berpengetahuan kurang 5 orang $(15 \%)$, sangat sedikit dari responden 5 orang (15\%) yang berpengetahuan cukup dan sebagian besar dari responden 24 orang (70\%) berpengetahuan baik.

Ada beberapa pertanyaan dalam menguji pengetahuan tentang resiko tinggi kehamilan yang secara umum tidak dapat dijawab dengan benar oleh responden yaitu pertanyaan berapa tahun jarak untuk hamil selanjutnya setelah melahirkan yang tergolong resiko tinggi sebanyak 23 orang $(67,6 \%)$ yang menjawab salah. Peneliti berpendapat keinginan ibu untuk hamil dapat mempengaruhi resiko tinggi kehamilan dikarenakan ibu yang menginginkan kehamilan itu akan benar-benar mempersiapkan masa kehamilannya dan waktu persalinannya dengan baik dan cermat.

Hal ini sependapat dengan teori yang dikemukakan Notoatmodjo (2010) Pengetahuan merupakan hasil tahu dan ini terjadi setelah seseorang melakukan penginderaan terhadap suatu objek tertentu. Penginderaan terjadi melalui penglihatan, penciuman, rasa, raba dan sebagian besar pengetahuan manusia diperoleh melalui mata dan telinga.

Hasil penelitian ini sesuai dengan teori Maulana (2009), menyatakan bahwa pengetahuan atau kognitif merupakan domain yang sangat penting dalam membentuk tindakan atau sikap seseorang. Kecendrungan seseorang untuk memiliki motivasi atau keinginan berperilaku kesehatan yang baik dipengaruhi oleh tingkat pengetahuan, sikap dan keterampilan.

Selain itu penelitian yang sejalan yaitu penelitian yang dilakukan oleh Sari, dkk tahun 2015 mengenai faktor pendidikan, pengetahuan, paritas, dukungan keluarga dan penghasilan keluarga yang berhubungan dengan pemanfaatan pelayanan antenatal. Adapun hasil uji hipotesis chi square dengan taraf signifikasi yang diambil sebesar 5\% maka nilai korelasi yang ditunjukkan adalah 0,001 Menunjukkan bahwa ada hubungan antara tingkat pengetahuan dengan pemanfaatan pelayanan antenatal.

Oleh sebab itu, petugas kesehatan dalam melakukan asuhan sebaiknya memberikan pengertian yang baik dan jelas mengenai apa saja yang termasuk dalam resiko tinggi kehamilan itu sendiri dan cara mengatasinya sehingga dapat resiko yang dihadapi ibu dapat di atasi dan tidak berdampak buruk baik bagi ibu maupun janin.

Berdasarkan hasil penelitian yang dilakukan terhadap 34 responden didapatkan sebagian kecil dari responden 7 orang (21\%) memiliki sikap tidak mendukung dan sebagian 
besar dari responden 27 orang (79\%) memiliki sikap yang mendukung.

Ada beberapa pertanyaan dalam menguji sikap dalam pemeriksaan antenatal care yang secara umum tidak dapat dijawab dengan benar oleh responden yaitu pertanyaan Jadwal kunjungan selama hamil paling banyak 4 kali sebanyak 15 orang $(44,1 \%)$ yang menjawab salah. Peneliti berpendapat ibu yang menikah muda menyebabkan banyak terjadi kehamilan pada usia berisiko tinggi, ibu masih beranggapan bahwa kehamilan dan persalinan merupakan sesuatu yang alami yang tidak berarti tidak memerlukan pemeriksaan dan perawatan khususnya melakukan kunjungan antenatal care secara baik.

Menurut Notoatmodjo (2010) bahwa pandangan/perasaan yang disertai kecenderungan untuk bertindak sesuai dengan sikap yang objek. Jadi sikap senantiasa terarah terhadap suatu hal, suatu objek,tidak ada sikap yang tanpa objek. Manusia dapat mempunyai sikap terhadap bermacam-macam hal. Sedangkan teori menurut Maulana (2009) yang menyatakan bahwa sikap merupakan kecendrungan merespon (secara positif atau negative) orang, situasi atau objek tertentu. Sikap mengandung suatu penilaian emosional atau efektif (senang, benci dan sedih).

Selain itu penelitian ini tidak sejalan dengan penelitian yang dilakukan oleh Komariah tahun 2008 mengenai hubungan pengetahuan, sikap dan perilaku ibu hamil tentang pemeriksaan kahamilan dengan kunjungan pemeriksaan kehamilan di wilayah kerja Puskesmas Sukorame Mojoroto Kediri. Adapun hasil penelitian didapatkan tidak ada hubungan yang signifikan antara sikap dan kunjungan pemeriksaan ibu hamil (nilai $r$ sebesar 0,149 dan p sebesar 0,032).

Analisis Bivariat yang dilakukan adalah tabulasi silang antara dua variabel yaitu variabel independen dan variabel dependen. Analisis bivariat yang digunakan untuk mengetahui adanya hubungan antara pengetahuan tentang resiko tinggi kehamilan dengan sikap dalam pemeriksaan antenatal care (ANC) di Puskesmas Sungai Raya Dalam tahun 2017 adalah menggunakan metode analisis data non parametric dengan uji statistik yang digunakan Chi Square dengan derajat kemaknaan 5\% atau $(0,05)$.

Dari hasil uji statistik menggunakan Chi Square, hasil perhitungan X2 hitung sebesar 8,27 sedangkan angka pada tabel chi square kuadrat tahap signifikasi 5\% = 2 adalah 5,991 Dengan demikian berarti 8,27>5,991 maka perhitungan Ho ditolak dan Ha diterima dapat disimpulkan bahwa terdapat hubungan antara pengetahuan tentang resiko tinggi kehamilan dengan sikap dalam pemeriksaan antenatal care.

Hal ini sependapat dengan hasil penelitian yang dilakukan oleh Komariayah (2008) mengenai hubungan pengetahuan, sikap dan perilaku ibu hamil tentang pemeriksaan kehamilan dengan kunjungan pemeriksaan kahamilan di wilayah kerja Puskesmas Sukorame Mojoroto Kediri. Memiliki hasil penelitian dengan $\mathrm{p}=0,007$ berarti ada hubungan yang signifikan antara tingkat pengetahuan dengan kunjungan pemeriksaan kehamilan. 
Demikian pula dengan hasil penelitian yang dilakukan oleh Sari, dkk (2014) yang berjudul faktor pendidikan, pengetahuan, paritas, dukungan keluarga dan penghasilan keluarga yang berhubungan dengan pemanfaatan pelayanan antenatal diperoleh tingkat pengetahuan tentang pemanfaatan pelayanan antenatal terdapat hubungan yang signifikan pada taraf 0,05 dengan nilai $\mathrm{p}=$ 0,001 .

Secara statistik ada hubungan dapat ditinjau dari data yang memperlihatkan bahwa responden dengan tingkat pengetahuan yang baik dengan sikap yang mendukung hampir seluruh responden 22 orang (81\%) sedangkan sangat sedikit dari responden 2 orang $(8 \%)$ yeng memiliki tingkat pengetahuan kurang dengan sikap yang mendukung. Sikap yang mendukung lebih banyak terjadi pada responden dengan pengetahuan yang baik dibandingkan sikap yang tidak mendukung. Sedangkan responden yang pengetahuannya kurang dengan sikap yang mendukung yang dialami rendah dibandingkan dengan responden yang memiliki sikap yang tidak mendukung.

Hal ini dapat disebabkan karena pengetahuan yang baik akan berdampak pada sikap seseorang. Sehingga semakin baik pengetahuan yang dimilikinya. Menurut Notoatmodjo (2010) Pengetahuan merupakan hasil tahu dan ini terjadi setelah seseorang melakukan penginderaan terhadap suatu objek tertentu. Penginderaan terjadi melalui penglihatan, penciuman, rasa, raba dan sebagian besar pengetahuan manusia diperoleh melalui mata dan telinga.

\section{Kesimpulan}

Hasil uji statistik menggunakan Chi Square, hasil perhitungan X2 hitung sebesar 8,27 sedangkan angka pada tabel chi square kuadrat tahap signifikasi 5\% = 2 adalah 5,991. Dengan demikian berarti 8,27 > 5,991 maka perhitungan Ho ditolak dan Ha diterima dapat disimpulkan bahwa terdapat hubungan antara pengetahuan tentang resiko tinggi kehamilan dengan sikap dalam pemeriksaan antenatal care.

\section{Daftar Pustaka}

Agustini, Sri, 2012. Pengetahuan ibu hamil tentang tanda - tanda bahaya kehamilan di Wilayah Kerja UPT Puskesmas Cimandala Kecamatan Sukaraja Kabupaten Bogor. Skripsi fakultas kesehatan masyarakat, UI: Depok

Arikunto, S. 2006. Prosedur Penelitian Suatu Pendekatan Praktisi. Jakarta: Rineka Cipta

Alimul Hidayat, A. Aziz. 2014. Metode Penelitian Kebidanan Dan Teknik Analisis Data. Jakarta: Salemba Medika

Dharma, Kelana Kusuma. 2012. Metodologi Penelitian Keperawatan Panduan Melaksanakan dan Menerapkan Hasil Penelitian. Jakarta: Trans Info Media

Imron, Moch. 2010. Metodologi Penelitian Bidang Kesehatan. Jakarta: Sagung Seti

Indriarti. 2015. Paduan Terbaik Kehamilan, Persalinan dan Perawatan Bayi. Yogyakarta: Indoliterasi

Lalage Zerlina. 2013. Menghadapi Kehamilan BeresikoTinggi. Klaten: Abata Press

Lockhart \& Lyndon. 2014. Asuhan Kebidanan Patologi.Tangerang: Binarupa Aksara Publiser 
Kemenkes RI. 2016. Agenda SDGS dalam Rakerkenas 2016. Diakses tangga 6 April 2017

Komariyah. 2008. Hubungan pengetahuan, sikap dan perilaku ibu hamil tentang pemeriksaan kehamilan dengan kunjungan pemeriksaan kehamilan di Wilayah Kerja Puskesmas Sukorame Mojoroto Kediri, Thesis Program Studi Magister Kedokteran Keluarga Universitas Sebelas Maret

Kuswanti Ina. 2014. Asuhan Kehamilan.Yogyakarta:Pustaka pelajar

Manuaba Ida Bagus Gede. 2012. Buku Ajar Pengantar Kuliah Teknik Operasi Obstetri \& Keluarga Berencana.Jakarta: CV. Trans Info Media

Manuaba, Ida Ayu Chandra Nita, dkk. (2009). Buku Ajar Patologi Obstetric Untuk Mahasiswa Kebidanan. Jakarta: EGC

Marmi. 2014. Asuhan Kebidanan Pada Masa Antenatal. Yogyakarta: Pustaka belajar

Maulana, Heri DJ. 2009. Promosi kesehatan. Jakarta: EGC

Mufdlilah. 2009. ANC Fokus Antenatal Care Focused. Yogyakarta: Nuha Medika

Nugroho Taufan dan Utama Bobby Indra. 2014. Masalah Kesehatan Reproduksi Wanita.Yogyakarta: Nuha Medika

Notoatmodjo, S. 2010. Promosi Kesehatan Teori dan Aplikasi. Jakarta: Rineka Cipta

Pantikawati Ika dan Saryono. 2010. Asuhan Kebidanan 1 (Kehamilan). Yogyakarta: mulia medika

Prawirohardjo, Sarwono. 2009. Pelayanan Kesehatan Maternal Dan Neonatal. Jakarta: PT Bina Pustaka

Prawihardjo, Sarwono. 2012. Ilmu Kebidanan.: Jakarta: PT. Bina Pustaka Sarwono Prawirohardjo

Profil Kesehatan Kota Pontianak. 2015. Laporan Akuntabilitas Instansi
Pemerintah (LAKIP) DInas Kesehatan Tahun 2015: Pontianak

Profil Kesehatan Kabupaten Kuburaya Tahun. 2015

Rukiah Ai Yeyeh, dkk. 2013. Asuhan Kebidanan 1 Kehamilan. Jakarta: Trans Info Media

Sari, dkk. 2014a. Faktor-faktor yang berpengaruh terhadap resiko kehamilan ' 4 terlalu (4-T)' pada wanita usia 10-59 tahun (analisis Riskesdas 2010). Pusat Teknologi Intervensi Kesehatan Masyarakat, Badan Litbangkes, Kmenkes RI: Jakarta

2014b. Faktor pendidikan, pengetahuan, paritas, dukungan keluarga dan penghasilan keluarga yang berhubungan dengan pemanfaatan pelayanan antenatal. Dosen jurusan kebidanan Poltekes Kemenkes Jakarta 3

Saifuddin Abdul Bari.2009. Buku Acuan Nasional Pelayanan Kesehatan Nasional Maternal Dan Neonatal.Jakarta: PT Bina Pustaka Sarwono Prawirohardjo

Siswanto, dkk. 2014. Metodologi Penelitian Kesehatan dan Kedokteran. Yogyakarta: Bursa Ilmu Karangkajen

Sukarni Icesmi \& Margareth. 2013. Kehamilan, Persalinan, dan dilengkapi dengan Patologi. Yogyakarta: Nuha Medika

Sulistiyanti. Anik. 2014. Hubungn Usia dan Pendidikan Ibu Hamil Resiko Tinggi dengan Kepatuhan Antenatal Care. ISBN:978-602-73865-4-9: Surakarta

Sujati. 2013, Gambaran Pengetahuan Ibu Hamil Tentang Kehamilan Resiko Tinggi. Karya Tulih Akhir Universitas Muhamadiyah Ponorogo

Syafuddin, Ali Akhmad.2009. Panduan Lengkap Kehamilan, persalinan dan Perawatan Bayi. Jogjakarta: Diglossia Media

Syafrudin dan Fratidhina Yudhia. 2009. Promosi Kesehatan Untuk Mahasiswa 
Volume 7 Nomor 1 Tahun 2017

Kebidanan. Jakarta: CV. Trans Info Media.

World Health Organization (WHO). 2015. Angka Kematian Ibu. 